\title{
The role of internal auditing in corporate governance: a Foucauldian analysis
}

\author{
Dessalegn Getie Mihret ${ }^{\dagger}$ \\ Deakin University, Melbourne, Australia \\ Bligh Grant \\ University of Technology, Sydney, Australia
}

\begin{abstract}
Purpose - This study attempts to articulate the conceptual foundations of the role of internal auditing in corporate governance by drawing on Michel Foucault's concept of governmentality.
\end{abstract}

Design/methodology/approach - The paper is a literature-based analysis of the role of internal auditing from a Foucauldian perspective.

Findings - It is argued that Foucault's notion of governmentality provides conceptual tools for researching internal auditing as a disciplinary mechanism in the corporate governance setting of contemporary organizations. The paper develops an initial conceptual formulation of internal auditing as (a) ex post assurance about the execution of economic activities within management's preconceived frameworks and (b) ex ante advisory services to enhance the rationality of economic activities and accompanying controls.

Originality/value - This paper extends the Foucauldian analysis of accounting to incorporate internal auditing. It offers original propositions as a research agenda and discusses ontological and epistemic considerations associated with adopting the Foucauldian framework for internal auditing research.

Implications - The paper is expected to initiate debate on the choice of theory and method in internal auditing research. The propositions and research agenda discussed can be used to address research questions of an interpretive nature that could enrich our current understanding of internal auditing.

Keywords Corporate governance; Foucault; Governmentality; Internal auditing; Enterprise risk management; Power

\section{Paper type Research paper}

${ }^{\dagger}$ Address for correspondence: Deakin University, Melbourne VIC 3125, Australia; E-mail: dmihret@deakin.edu.au; Phone: +61392445202

\section{Introduction}

Internal auditing remains a neglected area of research (Gendron and Be'dard, 2006; Roussy, 2014), despite its rise as an integral component of the corporate governance fabric of contemporary organizations, particularly in the wake of the spate of corporate collapses of the 1990s and 2000s (Carcello et al., 2005a; Sarens et al., 2009; Maijoor, 2000; Gramling et al., 2004). The function has increasingly been regarded as a key component of risk management (Spira and Page, 2003; Selim and McNamee, 1999; Arena et al., 2010; de Zwaan et al., 2011 ; Leung et al., 2003) that helps organizations fulfill corporate goals (Spira and Page, 2003; Gramling et al., 2004). The Institute of Internal Auditors (IIA) [1] defines internal auditing as "an independent, objective assurance and consulting activity designed to add value and improve an organization's operations." It further elaborates that internal auditing "helps an 
organization accomplish its objectives by bringing a systematic, disciplined approach to evaluate and improve the effectiveness of risk management, control, and governance processes" (Institute of Internal Auditors, 2004, emphasis added) [2]. The agency theory perspective (Jensen and Meckling, 1976), which continues as the dominant theoretical view informing internal auditing research (Adams, 1994; Mihret, 2014), has contributed to the internal auditing literature grounded in the positivist research approach. Under this research tradition, the origin of the demand for internal auditing is traced to the contractual relationships between management and shareholders of firms as part of addressing the agency problem in shareholder-manager relationships (Healy and Palepu, 2001). Nevertheless, agency theory's explanation for the demand for internal auditing rests on the theory's underpinning positivist ontological assumption that empirical phenomena represent an objective reality unaffected by context - a view that can be challenged from interpretive research perspectives.

The argument of the present paper is based on the premise that the predominant choice of a positivist approach to internal auditing research leads to conceptualizing the function as a neutral technical tool and that this results in neglecting the complex social context in which internal auditing is deployed as a technology for exercising power. Innovative theoretical approaches, increasingly advocated for accounting and auditing research (Guthrie and Parker, 2012), therefore, are needed to address such theoretical difficulties by enabling us to understand complex phenomena in their contexts (Parker, 2008). The Foucauldian framework is one possible approach that can be employed for this purpose. It has been used in major streams of accounting research to explain how systems, practices, and techniques are implicated in the exercise of power (Townley, 1993; Miller and Rose, 1990). Specifically, the literature illustrates that financial accounting makes organizational activities increasingly governable by rendering them measurable and visible (Hines, 1988; Morgan, 1988) and that management accounting provides further tools and vocabularies that enable management actions in the planning and control of organizations (Preston, 1992; Loft, 1986; Robson, 1992; Miller and O'leary, 1987). Auditors serve in this context as an added layer of governance by subjecting outputs of accounting to independent verification, investigation, and evaluation, as illustrated in Radcliffe's (1999; 1998) analysis of public sector efficiency auditing.

Despite the rising significance of internal auditing and its development as a distinct subdiscipline aiming to "help" management foster organizational goal achievement (Roussy, 2013), it has surprisingly not received Foucauldian intellectual consideration, arguably due to the supposition that internal audit work overlaps with external, i.e., financial, auditing. As the IIA's latest survey of North American chief internal audit executives and internal auditors (IIA, 2014) indicates, financial audit activity only constitutes $9 \%$ of internal auditors' scope of work [3]. Internal auditors offer direct insights through recommendations for management action (Chambers, 2014), thereby providing 'support' and 'guidance' to management (see, for example, Roussy, 2014). Consistent with this claim, internal auditors tend to side with management when they face situations of divided loyalties between management and the board of directors (see, for example, Roussy, 2013). This contrasts with external auditors' virtue of keeping distance from client management to advance the public interest.

Commensurate with its distinct current standing, internal auditing has followed a historical path separate from financial accounting, management accounting, and external audits of financial statements. Before the 1940s, the main focus of internal auditing was checking the propriety of transactions and records. In the 1940s, the development of an information 
economy based on the concept of "systems" facilitated the emergence of contemporary internal auditing with a focus on the evaluation of such systems (McNamee and McNamee, 1995) matched with a focus on systems that gradually replaced the emphasis on activities (Power, 1994) as a cardinal management approach and the modality of exercise of power.

The current definition of internal auditing highlighted above reflects the Committee of Sponsoring Organizations' broad conceptualization of internal controls and the integration of controls in Enterprise Risk Management (ERM) (Committee of Sponsoring Organisations, 2004). The ERM framework emphasizes the importance of risk management in corporate governance and the role of mechanisms such as internal auditing in this process. Thus, internal auditing is interpreted in this paper as a risk-management technology that provides $e x$ ante advisory and ex post assurance services by identifying areas of an organization that could lead to failure to achieve organizational goals. Prima facie, attaining organizational goals is premised on the ability of management to manage risk, which involves defining goals, identifying risk drivers, and implementing appropriate risk responses and the social relations in which controls are exercised. Internal audit's advisory role (Institute of Internal Auditors, 2012) can be interpreted as proactively recommending appropriate responses for addressing risk, and its assurance role (Institute of Internal Auditors, 2012) can be understood as a post hoc evaluation of risk to assist organizations in fending off possible future obstacles to their corporate objectives (Sarens and Beelde, 2006), particularly wealth creation and preservation. This role of internal auditing in risk management within the firm is also distinct from potential investors', creditors', shareholders', and other parties' use of audited financial information to manage risks associated with their business dealings with the firm.

Against this background, we explore the conceptual foundations of internal auditing as a distinct corporate governance technology using the concept of governmentality originating with the work of Michel Foucault, and we offer a research agenda consistent with Foucauldian ontological and epistemological positions (see, for example, Dean, 1999, pp. 1019; Esmark, 2015). Governmentality comprises the concepts of government and rationality. On this account, government is understood "not just [as] a power needing to be tamed or an authority needing to be legitimized"; rather, it "is an activity and an art which concerns all and touches each" (Burchell et al., 1991, , p. x; emphasis added). As such, government is not confined to institutional structures of authority. Rather, it is a pervasive empirical phenomenon, the characteristics of which are nevertheless specific to particular sites, practices, and organizations. On this account, rationality is understood as the need to know what is being governed in order to direct activity toward achieving certain ends (Neu, 2006; Miller and O'leary, 1987). Previous work on governmentality has emphasized that the operation of governmental power makes "action at a distance" possible in the management (Armstrong, 1994) of complex organizations through the translation of distant reality into stable, movable, and combinable forms (Robson, 1992). More recently, and capturing the core of Foucault's $(1977 ; 1978)$ working of the idea, governmentality has been described as "a particular, regulatory game of freedom and security" (Esmark, 2015, p. 21). It is these ideas that we apply to the operation of internal auditing here.

The remainder of this paper is structured as follows. The next section develops a conceptual framework for the paper by outlining Michel Foucault's concept of governmentality and exploring some recent work theorizing the concept. The ensuing section articulates the role of internal auditing in contemporary corporate governance using the framework developed in the second section. The final section concludes the paper by drawing on research implications of the analysis. 


\section{Governmentality}

In attempting to formulate a conceptual basis of the role of internal auditing in corporate governance, we employ, as an illustrative lens, the function's role in assisting management and the board of directors to manage risk. The Foucauldian concept of governmentality (Foucault, 1980) provides useful insights into this endeavor, and it has been increasingly adopted in accounting and management research (Carter et al., 2002). We have noted that the term is derived from the concepts of government and rationality ("governmental rationality"). In the case of government, it is necessary to comprehend both the epistemic and the ethical status of this phenomenon as an "art" rather than the exercise of legitimate authority. Furthermore, at a particular point in his work, Foucault (1977) investigated the transposition of sovereign power from the site of the monarch to the modern state, where the latter was defined in terms of institutionally specific practices (the Benthamite prison, for example). However, rather than governmentality merely being a totalizing instrumental/moral narrative - and despite the fact that, as Gordon (1991, p. 3) observed, Foucault saw it as characteristic of Western societies to both "totalize" and "individualize"-governmentality is equally applicable to technologies of "micro-power" and the corporation, for example, as it is to public institutions charged with tax collection, law and order, and national defense. Foucault (1991, p. 54) was clear in this regard and, while his own investigations ranged across the development of the modern prison (Foucault, 1977) as well as psychology and medicine (see, for example, Foucault, 1981), scholars deploying this approach have applied it to a diverse range of phenomena (see, for example, Dean and Hindess, 1998). Integral to the concept of governmentality, rationality refers to the centrality of knowing what is being governed to ensure goals are met (Townley, 1993). As such, the two phenomena are inextricably bound: the desirability of government requires not merely knowledge of what is to be governed, which is necessarily post facto, but knowledge of that subject when it is being governed, which is necessarily ex ante and thereby involves the calculation of risk (see, for example, Defert, 1991; Ewald, 1991). Furthermore, in his essay "Governmentality", Foucault (1991, p. 92) observed that "[t]he art of government ... is essentially concerned with answering the question of how to introduce economy - that is to say, the correct manner of managing individuals, goods and wealth within the family" (emphasis added). This is immediately paralleled with the conception of the modern state, where "the essential issue in the establishment of the art of government [is the] introduction of economy into political practice" (Foucault, 1991, p. 92).

As an element of Foucault's work generally, as well as the scholarly literature examining the topic, governmentality has several other notable features, themes or broad propositions that are relevant for our discussion here. First, governmentality is grounded in the notion of power/knowledge, which we have discussed here in relation to the more specific concept of rationality but which is nevertheless more broadly applicable to systems of knowledge and indicates the constitutive relation between knowledge and power in the sense that the acquisition of knowledge is integral to the exercise of power (Foucault, 1980). The notion of power/knowledge underpins various technologies that render phenomena knowable and thus governable. The nature of Foucault's concept of power (Miller and O'leary, 1987) requires an understanding of individuals as self-regulating agents (Foucault, 1982). However, this does not imply individual freedom in a political or liberal sense: the theory of governmentality presumes that individuals are accorded "regulated autonomy" in the exercise of control (Miller and Rose, 1990; Rose and Miller, 1992; Miller and Rose, 2008). Stated differently, the theory of governmentality asserts that: "To govern individuals is to get them to act and to 
align their particular wills with ends imposed on them through constraining and facilitating models of possible actions. Government presupposes and requires the activity and freedom of the governed" (Burchell, 1991, , p. 119; emphasis added).

Second, the concept of surveillance, as exemplified by Bentham's (1995) panopticon, forms a core analogy in Foucault's account of the operation of governmentality (see, in particular, Foucault, 1977). Originally, Bentham (1995) presented the panopticon as a model for an effective prison. Nevertheless, he also used the concept as a central tenet of his principles of good management (Gallhofer and Haslam, 1993, , p. 320). He explained that the idea of the panopticon can be applied "to the purposes of perpetual prisons in the room of death, or prisons for confinement before trial, or penitentiary-houses, or houses of correction, or workhouses, or manufactories, or mad-houses, or hospitals, or schools". The idea of the panopticon also comprises Bentham's concept of "publicity", or transparency, which is held as a central tenet of contemporary good governance across private corporations and public administrations (Hood, 2010). According to this principle, management attempts to reduce inefficiency and mismanagement to avoid the undesired publicity of such matters. Thus, Bentham maintained that transparency of organizations in the public context leads to good performance from both moral and economic perspectives (Holland and Foo, 2003).

To appreciate the Foucauldian concept of governmentality, it is important be attuned to the subtleties of the metaphor of the panopticon. Governmentality is not accurately characterized merely by individuals' compliance to predetermined standards or measures. Rather, it is in the act of conducting (Deleuze, 1988, , p. 10) their own activities at work or in the context of incarceration (for example) that individuals are necessarily accorded the autonomy to comprehend and discipline themselves. This by no means implies that they can do anything they wish. On the contrary: a particular individual will know, in essence, the fundamental parameters of the game - so, for example, they might be remunerated amount ' $A$ ' to work hours ' $\mathrm{H}$ ' to produce an expected outcome ' $\mathrm{O}$ '-yet they are afforded the opportunity of gaming the system in a particular, broad direction (toward increased productivity, to explore innovative techniques of production, etc.). This concept of autonomy, exemplified in allowing individuals to self-regulate, is an essential element of governmentality. Furthermore, we suggest that the act of self-regulation-implying the autonomy to do so and how this then relates to the systematic coherence of the organization-more accurately depicts governmentality in a Foucauldian sense, or what Deleuze (1988) described as Foucault's "functional" analysis of power [4].

Third, the presence of distance necessitates the use of technologies to make possible the taking of control actions at distant sites (Latour, 1978, , p. 222). Distance entails the problem of control, and overcoming this problem necessitates the use of technologies of translation (Robson, 1992). Latour (1978, p. 223) argues that acting at a distance becomes possible trough translation 'by inventing means that: (a) render [the objects of control] mobile so that they can be brought back [to the center]; (b) keep them stable so that they can be moved back and forth without additional distortion, corruption or decay; and (c) [make them] combinable so that whatever stuff they are made of, they can be cumulated, aggregated, or shuffled like a pack of cards' [emphasis added]. Thus, technologies enable the 'center' to take action at distant sites by virtue of the knowability rendered by the use of vocabularies that technologies provide (Armstrong, 1994). Utilizing this approach, accounting has been conceptualized as a technology that translates accountable activities of organizations through these attributes of technology of governance. The key feature of the translation technologies such as accounting is that they reduce ambiguity in understanding the phenomena to which they refer. Reduced 
ambiguity involves ensuring correspondence of the translated inscriptions with the reality to which they relate. Nevertheless, the task of translation, such as quantification, is prone to generating its own ambiguity (Robson, 1992). This ambiguity calls for auditors assurance services on the correspondence of the reports with the pertinent reality, as well as recommendations about control actions that management could take (see, for example, Roussy, 2013).

Fourth, if we allow for the concept of governmentality to be applied to the individual (ethical) level, through the organizational to societal level as suggested by Dean (1999, p. 13), it becomes a heuristic for both description and explanation at these levels of analysis. For example, in his recent discussion, Esmark $(2015$, p. 6) asserts that 'the term governmentality can simply be treated as a synonym of liberal government and governmental management'. For Esmark (2015, p. 1), liberal government (i.e., governmentality) is not 'a minimal government pursuing laissez-faire politics [rather, it] is an omnipresent form of government aiming to widen and deepen a particular game of freedom and security [emphasis added]':

Within the game of freedom and security, freedom is not a moral or a legal principle, nor a matter of fundamental rights or protection from intervention. Liberal government seeks to increase behavioral freedom based on an expected outcome and carefully calibrates and adjusts freedoms according to its ongoing calculus of freedom and security. Security is the cost of manufacturing freedom (Esmark, 2015, p. 20).

In this context, we take particular heed of Esmark's (2015, p. 25) comments regarding a revised method for analysis, namely: 'Rather than including the level of governmental technology directly in the analysis, the history of governmentality [also, we assert, the theory thereof as described above] enables the history of specific technologies such as contracts, budgets, evaluation schemas, auditing systems and so on against a background of overall governmental rationality and practice'. It is with such a frame in mind-particularly Esmark's (2015, p. 21) 'regulatory game of freedom and security', whereby freedom is both "constructed" and "consumed" to produce more security — that we examine internal auditing.

\section{Corporate governance, risk management, and internal auditing: development of propositions}

\section{Corporate governance}

Internal auditing is regarded as a corporate governance mechanism. Corporate governance emphasizes stewardship and firm performance goals (Keasey and Wright, 1993; Short et al., 1999). Short et al. (1999, , p. 338) underscore this balanced emphasis on both control and performance in conceptualizing corporate governance as "the mix of those devices, mechanisms, and structures which provide control and accountability while promoting economic enterprise and corporate performance." The control goal of corporate governance ensures that the stewardship responsibility of management to shareholders is fulfilled. On the other hand, the performance goal concentrates on enhancing the efficiency of the firm to increase shareholders' wealth (Hart, 1995; Keasey and Wright, 1993). Consistent with this understanding, the OECD conceptualizes corporate governance as "a set of relationships between a company's management, its board, its shareholders and other stakeholders." The OECD also elaborates that "[g]ood corporate governance should provide proper incentives for the board and management to pursue objectives that are in the interests of the company and its shareholders and should facilitate effective monitoring." In such a system of corporate governance, the board of directors is responsible for "strategic guidance of the company and effective monitoring of management" while the board is itself "accountable to the company 
and the shareholders" (OECD, 2004, p. 58). As COSO (Committee of Sponsoring Organisations, 2004, p. 1) explains:

Value is maximized when management sets strategy and objectives to strike an optimal balance between growth and return goals and related risks, and efficiently and effectively deploys resources in pursuit of the entity's objectives.

Corporate governance structures with accountability mechanisms become necessary because it is impractical to cover future eventualities in principal-agent contracts of organizations (Hart, 1995; Keasey and Wright, 1993; Shleifer and Vishny, 1997). The systems of corporate governance provide a framework that defines the rights and responsibilities of parties, legitimates their actions, and outlines the relationships of accountability (Macdonald and Beattie, 1993) against the background of fulfilling the firm's stewardship responsibility to shareholders and increasing shareholders' wealth. Systems of corporate accountability are established to "bridge the gap" between the expected and actual performance of the boards of directors (Huse, 2005, p. S67; Roberts et al., 2005). This accountability relationship of the board and shareholders extends to various levels of management and to employees. The logic of business activities and the benchmarks of their ex post evaluation, that is, audit (Keasey and Wright, 1993), are inscribed in organizational policies, procedures, plans, programs, and budgets. In this framework, management acts as an agent to control the firm's operations in accordance with corporate governance expectations.

The Blue Ribbon Committee (1999) presents audit committees, internal auditing, and external auditing as the "three-legged-stool" of corporate governance that enhances the reliability of financial reports. The enhanced focus on internal auditing as a means of fostering audit committee effectiveness and financial reporting quality (DeZoort et al., 2003), especially following the corporate collapses of the 1990s and 2000s (Johnson, 2007), signifies this recognition. The increased centrality of risk management and internal controls in corporate governance (Dewing and Russell, 2008; Power, 2004b) bears particularly farreaching significance as an illustrative lens through which to conceptualize the role of internal auditing in this context (Leung et al., 2011). Contemporary control practices cater to both stewardship and enterprise dimensions of corporate accountability goals (Turnbull, 1997), which can be affected by risk. Internal auditing can be conceptualized as one such mechanism that assists management and the board of directors to manage risk not only by identifying areas that warrant management intervention to ensure corporate goal achievement but also providing recommendations on appropriate management action. Despite variations in practices across countries (Demidenko and McNutt, 2010), risk management is regarded as a key component of corporate governance that enables organizations to fulfill goals (Subramaniam et al., 2009). Examining the role of internal auditing in the context of ERM, which is a central notion in the governance of contemporary organizations (Beasley et al., 2005; Gordon et al., 2009), clarifies the role of internal auditing as a risk management technology. COSO (Committee of Sponsoring Organisations, 2004) defines ERM as a: process, effected by an entity's board of directors, management and other personnel applied in strategy setting, and across the enterprise, designed to identify potential events that may affect the entity, and manage risk to be within its risk appetite, to provide reasonable assurance regarding the achievement of entity objectives.

Internal controls, with which internal auditing is closely associated, are regarded as a response to risk (Sarens and Beelde, 2006; Lenz and Hahn, 2015) and are integrated into ERM (Committee of Sponsoring Organisations, 2004). Thus, internal auditing can be conceived of as a technology enmeshed in the overall fabric of ERM-systems that are, broadly speaking, engaged in Esmark's (2015, p. 1) 'regulatory game of freedom and 
security'. Understanding this conception requires elaborating control rationalities under which internal auditing has been exercised. Management employs the control strategy of "responsible autonomy", which is consistent with the concept of regulated autonomy from the Foucauldian perspective (Miller and Rose, 1990; Rose and Miller, 1992). Consistent with the transformation from the use of sovereign power to disciplinary power to governmentality over the past two centuries (Foucault, 1977), contemporary control practices of organizations involve soliciting employees' consent, necessarily implying the freedom for them to so do. Controls, as an essential feature of organizations, aim to ensure circumscription of idiosyncratic behaviors and diverse interests of individuals in ways consistent with organizational rationalities (Tannenbaum, 1967), which remain a crucial notion in governmentality, yet not extinguish the space for devising systems of self-regulation. This notion indicates that because control and deviance tendencies are inherent in organizations, monitoring and assurance technologies (such as internal auditing) become crucial to ensuring broad conformity (Baldamus, 1961), yet they allow for the 'play' of both individuals and discrete units (departments; firms) within an organization. The aim of internal auditing as a risk-management technology is ensuring that not only are the rationalities ascribed to bureaucratic controls implemented but also that such rationalities are continually assessed for efficacy and appropriately enhanced. Such a technology adds higher-order knowability to those provided by the calculative technologies, organizational policies, and procedural frameworks in which economic activities are undertaken. The heightened emphasis of corporate governance on ERM helps "an entity get to where it wants to go and avoid pitfalls and surprises along the way" (Committee of Sponsoring Organisations, 2004, p. 1), and the role of internal auditing in this process provides a useful context for analysis. As highlighted earlier in this paper, it can be argued that the specific roles of internal auditors in corporate governance and its relationships with other components of corporate governance transform along with developments in the institutional landscape. Therefore, the following proposition is worth pursuing:

Proposition 1. Developments that transform the roles of boards of directors and management in corporate governance will drive a concomitant shift in the portfolio of internal auditing services.

\section{Internal auditing as a risk-management technology}

The increased size and complexity of organizations has made ERM a key issue in governing organizations (Beasley et al., 2005), which in turn has revitalized the role of internal auditing. Current thinking that risk management is fundamentally a control problem (Spira and Page 2003; Committee of Sponsoring Organisations, 1992) illuminates internal auditing as a riskmanagement technology deployed in making economic activities governable by providing assurance on organizations' systems, processes, and activities. Theory construction concerned with the risk-management rationale of internal auditing requires unpacking the concept of risk itself, alongside its management. Consistent with major roles of internal auditing highlighting the function's definition, COSO (Committee of Sponsoring Organisations, 2004, p. 2) explains the relationships among uncertainty, risk, and opportunities as follows:

Events can have negative impact, positive impact, or both. Events with a negative impact represent risks, which can prevent value creation or erode existing value. Events with positive impact may offset negative impacts or represent opportunities. Opportunities are the possibility that an event will occur and positively affect the achievement of objectives, supporting value creation or preservation. Management channels opportunities back to its strategy or objective-setting processes, formulating plans to seize the opportunities. 
Risk management involves three tasks: defining the goals of the organization, identifying the potential drivers of risk, and laying out appropriate risk responses (Ritchie and Brindley, 2007; Sitkin and Amy, 1992). The first two components in this process relate to the general principle of risk assessment. The response aspect is the principle of control action invoked to ensure that goals are achieved (Boehm, 1991). The complexity of an organization's activities and the external environment within which it operates mean that achieving its goals always carries the possibility of risk (Beasley et al., 2005). According to Beck (1992), contemporary society has reached a stage of development whereby risk is too great to be fully addressed through insurance, and its statistical prognosis is complex. While Beck (1992) pitched his notable argument mainly at a societal level, its implications for risk management at the microeconomic level are also evident (Spira and Page, 2003), as eventuation of risk at a societal level produces cascading effects upon individual organizations (Juttner et al., 2003; Christopher and Peck, 2004). The increasing complexity of business, coupled with external risk factors uncontrollable by microeconomic actors, requires that organizations govern risk through technologies that ensure "continuity of the past" (Aradau and Munster, 2007; Diprose et al., 2008). In the context of organizations, this is salient in the continuing to strive to achieve corporate goals.

The analytical space of the relationships between management and internal auditing demonstrates that internal auditing is a technology used to operationalize governmentality. Internal auditing uses identified evaluative frameworks to render auditees at distant sites governable by not only pointing out areas that need corrective action but also offering insights for management action. Some tools of governmentality can be applied in the absence of internal auditing. For example, organizational policies and the legal framework in which organizational activities are undertaken, as well as calculative systems such as management accounting and financial accounting, make governance possible. On top of these tools, independent diagnostic and evaluative reports by internal auditors enable management to take corrective action in selected areas of the organization based on the auditor's recommendations. Internal auditors provide their services on a broad range of areas; in contrast, external auditors focus on the financial aspects of the organization. For instance, the major concern of internal auditing with economy, efficiency, and effectiveness (Al-Twaijry et al., 2003; San Miguel and Govindarajan, 1984) - the 3Es-is closely intertwined with the notion of risk management and how risks are governed through technologies. This focus indicates that internal auditing assists management by identifying potential disturbances that may hinder organizations from achieving their goals. Within the framework of organizational policies and procedures that serve as control parameters, internal auditing assists the organization in managing risk in an assortment of its activities. It helps prevent future irregularities based on a post hoc evaluation, and it enhances economy, efficiency, and effectiveness (Al-Twaijry et al., 2003; Allegrini and D'Onza, 2003) through ex ante recommendations for appropriate management action. Internal audit reports also add credibility to self-produced information presented by the organizational components being evaluated. From the Foucauldian perspective, the individual is regarded as discursively constituted through the practices of power/knowledge (Armstrong, 1994), which makes governing economic life a complex practice in which both the management and employees exercise some power (Miller and Rose, 1990). This concept is particularly important for understanding internal audit's relationship with auditees in terms trust and cooperation. Along this line of thought, we forward the following proposition: 
Proposition 2. A surprise-audit strategy will produce compliant behavior in auditees by creating the impression of a possible audit at any time, even when limited capacity of the internal audit department makes it impractical to cover all components of an organization in an audit plan in any particular audit period.

Also, Foucault's concept of surveillance (panopticon) illuminates how internal auditing is deployed by management to induce subjects to police themselves, as the latter do not know when their activities would be subjected to audit examination. The presence of internal auditing generates a pattern of employee behavior that makes the discursive nature of the exercise of power evident. This interpretation enables us to conceptualize the preventive role of internal auditors in risk management. Furthermore, the Foucauldian concept of selfknowledge can facilitate auditees' control self-assessment used by internal auditors (Sarens and Beelde 2006) and is an integral part of rendering subjects governable (Foucault 1982). The whole process of internal audit evidence-gathering, undertaken with the cooperation of the auditee, presumes auditees' self-knowledge. Because the effectiveness of internal auditing as a surveillance mechanism depends on whether the auditee has knowledge of when audits are to be conducted, we forward the following proposition:

Proposition 3. A surprise-audit strategy will produce compliant behavior in auditees by creating the impression that they could be audited at any time, even when the limited capacity of the internal audit department makes it impractical to cover all components of an organization in an audit plan in any particular audit period.

Contemporary internal auditing has enhanced the quality of corporate governance, especially in more recent times (Cohen et al., 2004; Spira and Page, 2003), by assuring boards of directors about the proper management of risk (Carrington and Catasús, 2007; Sarens et al., 2009). The empirical literature provides evidence that companies' internal audit budgets tend to be high in organizations that are exposed to high risk (Carcello et al., 2005b) and committed to managing risk (Goodwin-Stewart and Kent, 2006). As Gramling et al. (2004, p. 194) state, internal auditing is considered a cornerstone of corporate governance that "serves as a resource to each of the other three cornerstones [i.e., board of directors, management and external auditors] of corporate governance." Furthermore, the enactment of the SarbanesOxley Act following the financial reporting scandals affirmed the importance of internal auditing (Carey et al., 2006). For instance, under this Act, companies listed on the New York Stock Exchange are required to maintain internal audit departments that assist audit committees in risk management by ensuring that sound internal controls are in place (Carcello et al., 2005b; Christopher et al., 2009; Gramling et al., 2004).

Organizations invest in control systems to increase productivity and maximize returns. Internal auditors' role in the mitigation of wastage of resources by deterring fraud (Raghunandan and Mchugh, 1994; Beasley et al., 2000; Mihret et al., 2010) can also be understood as originating from the risk-management imperative in this regard (Spira and Page, 2003), grounded in the use of technologies. Similarly, internal auditors' advice about the efficient and effective use of resources (Al-Twaijry et al., 2003) helps management address risks ex ante by identifying conditions that potentially hinder the enterprise from achieving its corporate goals and recommending solutions to address them. The ex post evaluation aspect of internal auditing promotes internal audit independence from management (Goodwin and Yeoh, 2001; Christopher et al., 2009), whereas the ex ante advisory role advocates the notion that internal audit operates as a partner of management 
(Roth 2000, 2002; Bou-Raad, 2000; Goodwin, 2004). The services of internal auditing cover a broad range of services, including operational, compliance/regulatory, Sarbanes-Oxley, information technology, financial, risk management, business strategy, corporate governance, and fraud (IIA, 2014). Discharging these broad sets of responsibilities demands a high level of professionalism and broad skillsets. Because a claim to expertise is a crucial element of professionals' perceived ability to address relevant societal problems (Miller and Napier, 1993), broadening the skillset of internal audit departments may influence the perceived value of the internal audit and its acceptance by internal audit stakeholders. Thus, the following propositions are worth pursuing:

Proposition 4. Broadening internal auditors' skillsets and enhancing the professionalism of internal auditors fosters the disciplinary power of internal auditing, thereby producing compliant behavior in auditees.

Proposition 5. Broadening skillsets and enhancing the professionalism of internal auditors fosters the acceptance of internal auditing by management, boards of directors, and auditees as an effective technology of governance.

Economic activities assembled around analytical platforms such as the value chain serve as objects of internal auditing. These tools illustrate how the relationships among various activities of organizations are configured toward the common goal that ties parts of the organization together. These types of tools help abstract, plan, and record an organization's economic activities on paper. Based on such translations of objects of control (Latour, 1986) into vocabularies of governmentality, internal auditors recommend to management improvements in the systems of the value-creation activities through the internal audit's focus on the 3Es. Various subsets of the value chain could be an object of internal audit reporting to top management. The articulation of economic activities in such conceptual platforms serves to translate phenomena into movable concepts and thus make them amenable for action at a distance (Latour, 1978). Thus, internal auditing can be viewed as a technique that facilitates management of the value chain by highlighting categories that need management action when potential or actual risks are identified. It fills the gap in any visibility of categories that could exist, because calculative technologies, including accounting, cannot eliminate ambiguity and bias. The discourse of risk management as a control problem (Rasmussen, 1997) is affirmed by the Combined Code (UK Financial Reporting Council, 1998) and COSO reports (Power, 2004a). In particular, the COSO framework's definition of internal control consolidates the risk-management conceptualization of internal controls (Committee of Sponsoring Organisations, 1992). COSO defines controls as:

a process, effected by an entity's board of directors, management and other personnel, designed to provide reasonable assurance regarding the achievement of objectives in the following categories:

Effectiveness and efficiency of operations;

Reliability of financial reporting

Compliance with applicable laws and regulations.

Such a broad concept of internal controls adopted in corporate governance creates opportunities for internal auditing to provide assurance and advisory services in the arena of risk management. In particular, the shift in top management responsibility, from compliance with policies toward a focus on key risks, has fostered the role of internal auditing. This shift has led to management assuming responsibility for internal control systems and boards of directors' responsibility expanding to incorporating organizational prosperity as well as 
accountability to shareholders (Spira and Page, 2003). Due to this shift in thinking about risk at the societal level (Aradau and Munster, 2007; Diprose et al., 2008), rational knowledge and calculation became crucial for carrying out informed control action (Miller and Rose, 1990). In line with this thinking, internal auditors' intimate knowledge of organizational idiosyncrasies and their role in risk management has been one of the major premises of the IIA's stand against outsourcing of internal auditing to external auditors (Covaleski et al., 2003; Rittenberg and Covaleski, 2001). Hence, it can be argued that the role of internal auditing has been expanding along with the risk-management imperatives in the audit universe. Dimensions of performance, risk drivers, exposures, and the responses that are applicable under the given circumstances (Ritchie and Brindley, 2007) are implied in the planning and execution of internal auditing, as suggested by the professional standards for the practice of internal auditing (Institute of Internal Auditors, 2012). In addition, the internal auditing professionalization literature suggests that despite the development of certification and international standards of performance for internal auditors, internal auditing has not yet developed as a fully-fledged profession with regulatory oversight (Arena and Jeppesen, 2010; Fogarty and Kalbers, 2000), and its ethical framework continues to be ambiguous (Everett and Tremblay, 2014, p. 182). The reporting relationship of internal auditing with the management and board of directors may also impact the performance of internal auditors (Everett and Tremblay, 2014; Roussy, 2014). This can lead to a lack of uniformity in the focus of internal auditing and the consolidation of management's use of internal auditing as a technology of governance at its disposal. Thus, we forward the following proposition:

Proposition 6. Internal auditing is a localized governance technology in an organization with standards of performance not necessarily circumscribed in professional standards of practice. Thus, approaches to assessing internal auditing as an effective disciplinary mechanism may be contingent upon the specifics of the organization, yet researchers should nevertheless be cognizant of a trend toward increased professionalization.

\section{Conclusion and research implications}

This paper has attempted to establish the conceptual foundations of the role of internal auditing in corporate governance using, as an illustrative lens, the function's role in assisting management in dealing with risk. It has argued that internal auditing can be conceptualized as providing: (a) ex post assurance about the execution of economic activities within management's preconceived frameworks and (b) ex ante advisory services that enhance the rationality of economic activities and the accompanying controls of organizations. Nevertheless, both activities allow room for Esmark's (2015) 'regulatory game of freedom and security' that nevertheless tends toward increased security. This overall heuristic does not discount that variations in corporate governance practices across both countries (see for example, Macdonald and Beattie, 1993) and companies can influence the power/knowledge dynamics of the governance setting. This discourse-specific and, thus, institution-specific understanding of the Foucauldian framework can be set against the tendency to view governmentality as an account of overarching power/knowledge, as cautioned against in our account of governmentality above and as explicitly rejected by Foucault (see, for example, Foucault, 1991, , p. 53). The way in which internal audit services are predominantly used may be influenced by key concerns and operating characteristics of the relevant governance framework.

Table 1 summarizes the six propositions developed in this paper and provides operationalization of the research agenda by presenting uninvestigated and/or under- 
investigated research questions suitable for future research as well as proposing suitable research approaches. As suggested in the first five propositions, the Foucauldian framework enables us to consider the social context of internal auditing to understand relationships of internal auditing with auditees, management, and boards of directors. This framework also enables organizations to gauge the effectiveness of internal auditing in view of the particular context in which internal auditing is employed as a technology of governance as conceptualized in the sixth proposition. Our interpretive research agenda caters to social aspects of internal auditing that are neglected in the economics-based, i.e., positivist studies that largely tackled questions founded in the realist ontological position (Chua, 1986). For example, prior research in internal auditing focuses on the association of testing hypotheses on internal audit quality and financial reporting fraud (e.g., Prawitt et al., 2009), internal audit outsourcing and the risk of fraudulent financial reporting (e.g., Prawitt et al., 2012), audit committee characteristics and the interaction of internal auditors with the audit committee (e.g., Raghunandan et al., 2001), and firm characteristics and the presence/absence of internal audit departments in an organization (Adams, 1994). As suggested in the propositions developed in the present study, addressing research issues such as how internal auditors manage conflicting demands of stakeholders (see, for example, Chambers, 2014) will extend emerging interpretive research in internal auditing (example, Everett and Tremblay, 2014; Roussy, 2014).

The research agenda offered in this study also addresses another key shortcoming of prior research that originates from the choice of the realist philosophical position and associated positivist research approaches. That is, prior research focused on essentially cross-sectional research questions. By contrast, the research questions that follow from our conceptualization of internal auditing accommodate emergent and developmental research issues in internal auditing such as those listed in Table 1. In terms of research approach, longitudinal research, including historical studies of the transformation of internal auditing along with changes in the institutional climate, could be undertaken, with flexible data sources spanning archival sources, interviews and surveys (detailed in Table 1 for each proposition). Such an interpretive research approach addresses the limitations associated with economic theorybased research in internal auditing that neglects relevant research issues involving development and change. Nevertheless, the last five propositions can also serve as a basis to develop hypotheses that can be tested in the cross-sectional sense, as shown by some of the research questions suggested. 
Table 1 . Summary of the research agenda

\begin{tabular}{|c|c|c|c|}
\hline Foucauldian propositions & Suggested research issues & Suggested research approach & Possible data source(s) \\
\hline $\begin{array}{l}\text { P1. Developments that transform the roles of boards of } \\
\text { directors and management in corporate governance } \\
\text { will drive a concomitant shift in the portfolio of } \\
\text { internal auditing services. }\end{array}$ & $\begin{array}{l}\text { - How does the role of internal auditors transform along with changes in the } \\
\text { institutional landscape? } \\
\text { - How do external institutional pressures and the perceived role of internal } \\
\text { auditors motivate internal audit adoption by organizations? } \\
\text {-How does the insourcing versus outsourcing of internal auditing influence } \\
\text { the way internal auditing is used as a technology? } \\
\text { - Which internal audit practices are generic and which are transient? }\end{array}$ & $\begin{array}{l}\text { - historical studies } \\
\text { - interpretive study based on a } \\
\text { longitudinal design }\end{array}$ & $\begin{array}{l}\text { - interviews, survey, and/or } \\
\text { review of organizational } \\
\text { records }\end{array}$ \\
\hline $\begin{array}{l}\text { P2. A surprise-audit strategy will produce compliant } \\
\text { behavior in auditees by creating the impression of a } \\
\text { possible audit at any time, even when limited } \\
\text { capacity of the internal audit department makes it } \\
\text { impractical to cover all components of an } \\
\text { organization in an audit plan in any particular audit } \\
\text { period. }\end{array}$ & $\begin{array}{l}\text { - How does the type of internal audit strategy influence auditee compliance } \\
\text { behavior of auditees? } \\
\text { - How do alternations in audit strategies influence the level of trust between } \\
\text { auditees and auditors? }\end{array}$ & $\begin{array}{l}\text { - interpretive study based on a } \\
\text { longitudinal design } \\
\text { - cross-sectional study }\end{array}$ & $\begin{array}{l}\text { - interviews, survey, and/or } \\
\text { review of organizational } \\
\text { records }\end{array}$ \\
\hline $\begin{array}{l}\text { P3. Auditees will tend to be suspicious of the role of } \\
\text { internal auditing and thus be minimalist in their } \\
\text { cooperation with (or support of) internal auditors } \\
\text { because auditing may be perceived as a surveillance } \\
\text { tool with a disruptive impact on the regular activities } \\
\text { of the organization. }\end{array}$ & $\begin{array}{l}\text { - How do auditees perceive internal auditors' role? } \\
\text { - What strategies do internal auditors employ to forester auditees' trust in } \\
\text { auditors? }\end{array}$ & $\begin{array}{l}\text { - interpretive study based on a } \\
\text { longitudinal design } \\
\text { - cross-sectional study }\end{array}$ & $\begin{array}{l}\text { - interviews, survey, and/or } \\
\text { review of organizational } \\
\text { records }\end{array}$ \\
\hline $\begin{array}{l}\text { P4. Broadening internal auditors' skillsets and } \\
\text { enhancing the professionalism of internal auditors } \\
\text { fosters the disciplinary power of internal auditing, } \\
\text { thereby producing compliant behavior in auditees. }\end{array}$ & $\begin{array}{l}\text { - Does the breadth of skillsets of internal auditors and their expertise } \\
\text { influence stakeholders' perception about internal auditors? }\end{array}$ & $\begin{array}{l}\text { - interpretive study based on a } \\
\text { longitudinal design } \\
\text { - cross-sectional study }\end{array}$ & $\begin{array}{l}\text { - interviews, survey, and/or } \\
\text { review of organizational } \\
\text { records }\end{array}$ \\
\hline $\begin{array}{l}\text { P5. Broadening skillsets and enhancing the } \\
\text { professionalism of internal auditors fosters the } \\
\text { acceptance of internal auditing by management, } \\
\text { boards of directors, and auditees as an effective } \\
\text { technology of governance. }\end{array}$ & $\begin{array}{l}\text { - Does the internal auditors' level of professional certification enhance the } \\
\text { perceived effectiveness of internal auditors? } \\
\text { - How is the service portfolio of internal auditing determined? }\end{array}$ & $\begin{array}{l}\text { - interpretive study based on a } \\
\text { longitudinal design } \\
\text { - cross-sectional study }\end{array}$ & $\begin{array}{l}\text { - interviews, survey, and/or } \\
\text { review of organizational } \\
\text { records }\end{array}$ \\
\hline $\begin{array}{l}\text { P6. Internal auditing is a localized governance } \\
\text { technology in an organization with standards of } \\
\text { performance not necessarily circumscribed in }\end{array}$ & $\begin{array}{l}\text { - How do professional standards of internal auditors translate into suitable } \\
\text { frameworks for localized internal audit practices while preserving the } \\
\text { sufficiency of the framework to provide a basis for minimum professional }\end{array}$ & $\begin{array}{l}\text { - interpretive study based on a } \\
\text { longitudinal design }\end{array}$ & $\begin{array}{l}\text { - interviews, survey, and/or } \\
\text { review of organizational }\end{array}$ \\
\hline
\end{tabular}


professional standards of practice. Thus, approaches to assess internal auditing as an effective

disciplinary mechanism may be contingent upon

specifics of the organization, yet researchers should

nevertheless be cognizant of a trend toward

increased professionalization. standards?

What local factors determine the extent of compliance of internal auditors with the professional standards of internal auditors?

- How do internal auditors manage issues of reconciling conflicting expectations of stakeholders such as the board, management, and employees? records 
The propositions are not necessarily supported under a positivist research approach, as our research agenda is grounded in the critical theoretical framework derived from understanding the logic of the panopticon, and the concept of individual autonomy as we have described it here is a necessary element of this operational logic. At the same time, undertaking an inquiry into the role of internal auditing deploying the Foucauldian propositions suggested here by no means implies that the results of empirical inquiry will confirm the assumptions of the theory; on the contrary. For example, Proposition 3, that auditees will tend to be suspicious of the role of internal auditing and thus be minimalist in their cooperation, could be thrown into question should a particular empirical study suggest that this is not so.

The proposed research agenda also recognizes that institutional explanations for the development of internal auditing merit consideration along with our Foucauldian explanation of internal audit services. The research agenda under Proposition 1 broadly accommodates institutional and professionalization issues. Institutional pressure in recent times emphasizes the assurance role of internal auditors (Miller and Napier, 1993), and regulators at the societal level have moderated the jurisdictional competition between internal and external auditors (Rittenberg and Covaleski, 2001). Another institutional issue is the restriction of outsourcing internal audit work to external auditors after the Sarbanes-Oxley Act and the resulting boundary definition between internal and external auditing (Arena and Jeppesen, 2010). The outsourcing of internal auditing as a "non-core" activity has challenged the quest for the professionalization of internal auditing because this quest has been premised on internal auditors' ability to provide value-adding services to the firm (Rittenberg and Covaleski, 2001). The association of internal audit outsourcing to the fall of Arthur Andersen and the subsequent mandating of in-house internal audit departments in some stock exchanges with associated prohibition of outsourcing to external auditors (Caplan et al., 2007) suggests that internal auditing is becoming part of the wider system of societal surveillance. Prior research evidence indicates that institutional pressure for more assurance-type activities of internal auditors serves only a temporary advantage, while it will undermine the professionalism of internal auditors over the long term (Nagy and Cenker, 2007). The recent development trends in internal audit practice along the value-adding direction as opposed to maintaining the narrower boundaries of assurance (IIA, 2014) illustrate the tension between institutional pressure and professionalization.

In conclusion, this study illustrates the potential of the Foucauldian framework to support internal audit research from the critical and interpretive perspectives advocated in this paper and which are also implicit in the propositions we suggest for further research. This framework provides conceptual tools to analyze how internal auditing fits into the spectrum of power technologies in a social context of governing organizations. Further research is needed to refine the arguments advanced here, and this necessitates noting the Foucauldian ontological position, which has methodological implications. That is, research pursuing the above propositions - or research more generally concerned with internal auditing deploying the Foucauldian framework-will depart from the positivist assumption that research phenomena are objective reality existing independent of their contexts. This departure is necessary if future research is to address a full range of research questions on internal auditing, thereby tackling questions neglected by prior research. In particular, the conceptual articulation of internal auditing presented in this paper advances internal auditing research by offering a framework that enables us to understand the how of internal auditing. This aspect has largely been ignored because of the inconsistency of its intellectual concern with the ontological assumptions of the positivist lens. 


\section{Notes}

[1] The US-based Global IIA provides professional certification and guidance to its more than 180,000 members worldwide working with local institutes in various countries (https://global.theiia.org/Pages/Institutes.aspx). Local institutes tend to have a degree of autonomy in their form of organization. For instance, the IIA-UK is organized as the Chartered Institute of Internal Auditors (http://www.iia.org.uk/), whereas local institutes in other countries such as Australia (http://www.iia.org.au/) follow the same form of organization as the Global IIA.

[2] The IIA also emphasizes in its position papers that an internal audit should maintain its independent objective assurance role in the effective operation of the risk-management system and that this role precludes internal auditors from being involved in decisions such as '[s]etting the risk appetite, [i]mposing risk-management processes, ... [t]laking decisions on risk responses, [i]mplementing risk responses on management's behalf, [and taking] [a]ccountability for risk management.' (The Risk and Insurance Management Society and The Institute of Internal Auditors 2012; The Institute of Internal Auditors 2004, , p. 2).

[3] Other roles include operational (24\%), compliance/regulatory (14\%), Sarbanes-Oxley (12\%), information technology (10\%), risk management (7\%), business strategy (6\%), corporate governance (4\%), fraud (4\%), and other (10\%) (IIA, 2014, p. 7). The survey results of the years 2012 and 2013 were also largely consistent with those of 2014.

[4] Yet this "functional" interpretation of governmentality -in any specific setting-is only the systemic appreciation thereof and derived from select writings of Foucault (see, in particular, Foucault, 1977). Dean (1999, p. 17) has emphasized that governmentality can be fruitfully examined by deploying four lines of inquiry: [i] ontologically, 'concerned with what we seek to act upon, the governed or ethical substance'; [ii] ascetics, 'concerned with how we govern this substance, the governing or ethical work'; [iii] deontologically, 'concerned with who we are when we govern in such a manner, our mode of subjectification, or the governable or ethical subject' and [iv]

teleologically, 'concerned with why we govern or are governed ... that which might be called the telos of government or ethical practices'. Our point in this context is not to investigate how these lines of inquiry might (or might not) be pursued in the context of an examination of internal auditing. Rather, it is to point out that they can be pursued as an element of governmentality. As such, the functional analysis of power is significantly augmented. 